\title{
Editorial
}

\section{Engulfing by lipids: a matter of taste?}

\author{
G Chimini*,1 \\ 1 Centre d'Immunologie, INSERM/CNRS de Marseille-Luminy, Parc Scientifique de Luminy Case 906, 13288 Marseille Cedex 09, France \\ * Corresponding author: G Chimini, Centre d'Immunologie, INSERM/CNRS de Marseille-Luminy, Parc Scientifique de Luminy Case 906, 13288 Marseille Cedex 09, \\ France
}

Getting rid of dead corpses is a tantalising effort. A continuous and conspicuous cell turnover is imposed by the apoptotic clock and challenges phagocytes both during embryonic development and in adult life. ${ }^{1,2}$ Macrophages, by far the most zealous phagocytes are typically in charge of the clearance of dying cells in vertebrates. ${ }^{3}$ This is not the case in the nematode $C$. elegans, where professional phagocytes do not exist and engulfment is the task of randomly selected bystander somatic cells. ${ }^{4,5}$ However, also in mammals, amateur phagocytes can substitute for professionals. The long term outcome of an amateur's take over has not been established so far although it is likely that deleterious immunological consequences may arise from the elusion of the 'safe clearance' orchestrated by macrophages. ${ }^{6-8}$ The study of perturbed engulfment patterns and their consequences in 'in vivo' models such as the macrophage less PU.1 null embryos ${ }^{9-12}$ or mice lacking engulfment receptors ${ }^{13-19}$ will be precious to elucidate the pathophysiological impact of an impaired clearance of cellular debris generated by the apoptotic program.

\section{Phosphatidylserine driven recognition and professionals}

The recognition and ingestion of apoptotic preys in mammals appears to be a complex process only hazily understood so far. Experimental evidence, mainly based on in vitro inhibitory assays, has implicated a number of surface receptors on the phagocyte side. Among them are lectins, scavenger class $A$ receptors (SR-A), the LPS receptor CD14, the integrins $\alpha \mathrm{V} \beta 3$ or $\beta 5$ acting alone or in concert with CD36, a scavenger receptor of $\mathrm{B}$ class (see for review ${ }^{6,20}$ ). Interestingly, functional records concerning all these molecules preexisted their implication in engulfment ${ }^{21-23}$ and actually in this precise framework their molecular interaction with the apoptotic surface is not at all clear as yet. An exquisite hallmark of engulfment, defined herein as the process of phagocytosis of cells committed to die, is a lipid-mediated recognition system, concerning concomitantly the phagocyte and the prey ${ }^{24-26}$ which is extensively discussed by Schlegel $^{27}$ and Fadok $^{28}$ in this issue. The exposure of increased amounts of anionic phospholipids, namely phosphatidylserine on the outer surface of the apoptotic prey was recognised several years ago as one of the earliest signs of membrane modification on committed cells. How the phagocytes instantly sense these modifications, remains yet to be established. In fact, a longstanding search for a specific phosphatidylserine receptor (PSR) has only recently led to the identification of a novel surface molecule highly conserved across evolution. ${ }^{29}$ This PSR is expressed by macrophagelike cells and fibroblasts and recognises stereospecifically phosphatidylserine, in contrast to previous candidate receptors, which failed to discriminate among phospholipid species. It is however too early to know how this molecule acts on the cell surface to trigger engulfment. In this context it is interesting to recall that, as elucidated by Tepper and coworkers, ${ }^{30}$ the exofacial flopping of phosphatidylserine, a phospholipid species usually segregated to the inner membrane leaflet, is only apparently a minor event but actually perturbs dramatically the interactions among the different lipids at the membrane and transiently scrambles the overall lipid arrangement across the bilayer. This dramatic membrane destabilisation may facilitate the profound structural and morphological change consequent to apoptotic commitment.

The ability to expose phosphatidylserine is, in addition, a competence factor for an efficient phagocyte, which like many activated or fusogenic cell types, shows an unscrupulous asymmetric distribution of phospholipids at the membrane in the absence of any apoptotic commitment. This mobility is determinant for engulfment since its inhibition by pharmacological interference pre-empts an optimal phagocytosis. ${ }^{25} \mathrm{ABC}^{31}$ the putative mammalian homologue of $C$. elegans engulfment gene $c e d-7^{32}$ is a key player there. Indeed, $A B C 1$ is essential for membrane cholesterol homeostasis, as demonstrated by studies on Tangier patients ${ }^{33-35}$ and $A B C 1$ null mice, ${ }^{13,36,37}$ and this stems from the $A B C 1$ involvement in the dynamic control of transbilayer lipid turnover. Given that the loss of $A B C 1$ function in mice leads to suboptimal engulfment by professional macrophages, ${ }^{13}$ we may assume that the biophysical properties of the membrane, as dictated by the arrangement of lipids across the bilayer, is crucial for initiating engulfment. This membrane-priming role for the ABC transporter is also supported by the work of R.H. Horvitz and collaborators ${ }^{38}$ in the nematode model system. They evidence in fact a crucial role for ced-7 in the membrane redistribution of the ced $-1^{38}$ receptor around the corpse to be engulfed.

The engulfment however can take place in the absence of the phosphatidylserine dependent pathway. Activated macrophages, i.e. professionals, are the only cells that, even if equipped with the complete set of engulfment receptors, select systematically the phosphatidylserinedriven recognition/engulfment pathway. Amateurs, in contrast, make most frequently use of integrins $(\alpha \mathrm{V} \beta 3$ or $\beta 5)$ as trigger molecules. ${ }^{39-45}$ Dendritic cells, whose profes- 
sional status as phagocyte is controversial, ingest slowly apoptotic cells (hours as opposed to minutes), prefer late apoptotic preys, neglect, as mentioned above, the phosphatidylserine-mediated pathway and ingest via an integrin-mediated system. ${ }^{46-48}$ Mesangial cells or retinal pigment cells when forced to ingest apoptotic preys behave similarly. Interestingly the surface occupation of integrins has been recently linked to the sequential membrane recruitment and activation of crkII/DOCK 180 and Rac1 in a signalling cascade activating ingestion. ${ }^{40}$ The crkll/DOCK 180/Rac1 pathway parallels perfectly that of the ancestors in $C$. elegans, respectively ced-2, ced-5 and ced-10. ${ }^{49}$

Whether the cell-specific use of receptors in mammals discloses major differences in further handling of the prey is to date an open and legitimate question. Professionals are faster eaters than amateurs and the pace of ingestion is likely to be crucial in vivo. It would not be that surprising if further investigation highlight a direct correlation between swiftness of ingestion and the identity of the upstream receptor. It is known that the triggering receptor can dictate the mechanics of ingestion in the case of phagocytosis of opsonised preys. Distinct morphological features follow in fact the engagement of either Fc receptors or complement receptors (CR3/CR4). ${ }^{50,51}$ If we extrapolate this to engulfment and also consider a differential usage of receptors by professionals and amateurs, we may envision multiple facets of the engulfment as a phagocytic event. This speculation has recently found support in a comparative study of engulfment dynamics and morphology by professionals (microglia) and non-professionals
(BHK and lens epithelial cells). ${ }^{52}$ This work highlights major differences in the behaviour of the two classes. The highly motile professionals ingest early apoptotic cells quickly after the first contact whereas the sessile nonprofessionals considerably delay ingestion after recognition. In addition, the presence of a membrane signal emerging only on ripe apoptotic cells appears to be required for initiating engulfment by non-professionals. As for now however it is not known whether and how these dramatic differences are related to the nature of the recognising receptor.

\section{The redundancy of engulfment receptors in mammals}

As previously underlined, a specialised high affinity engulfment receptor does not exist; the situation is essentially the opposite, and 'in vitro' even the combined inhibition of several receptors fails to completely prevent the clearance of apoptotic cells by phagocytes. This points out receptor redundancy as a major characteristic of the process, without providing any clue for the underlying rationale.

Redundancy of low affinity receptors may well act as a safety device; it reduces escape possibilities for the prey and multiplies the chances of an optimal clearance (Figure 1a). Translated in cell biology terms, this would mean that each engulfment receptor can trigger the ingestion of an apoptotic particle via a receptor-specific entry sites into a common effector cascade. Alternatively redundancy may
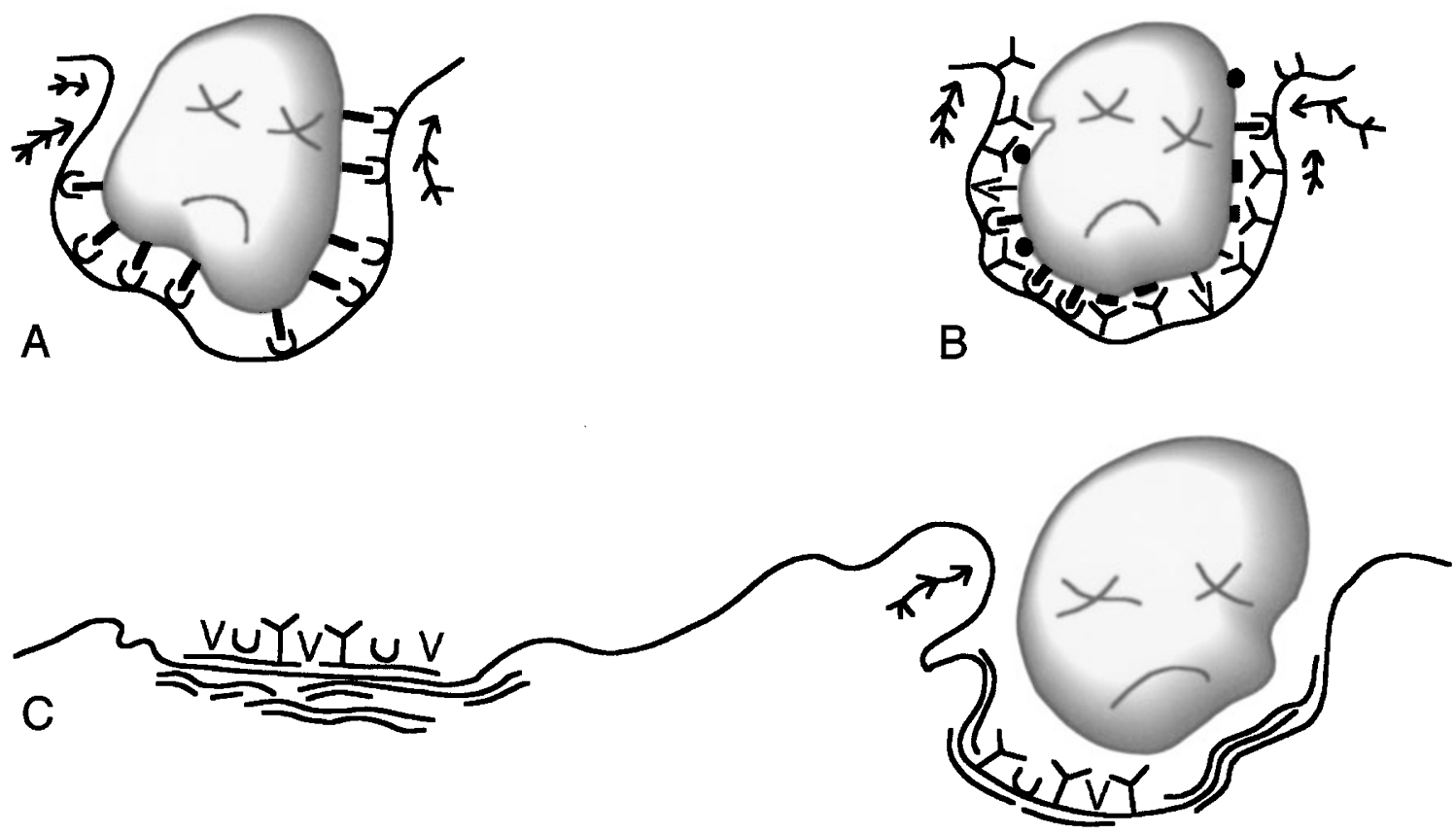

Figure 1 The redundancy of engulfment receptors and phagosome formation. (a) Each receptor is able and sufficient to trigger phagosome formation. The composition of phagosomes and the morphology of ingestion may thus vary accordingly to the triggering molecule. (b) Zippering mediated by recruitment of multiple receptors around an apoptotic corpse leads to the formation of phagosomes of similar membrane composition. (c) Engulfment starts at sites with peculiar membrane properties, where the engulfment receptors cluster, possibly with the help of ABC1. Symbols schematise the different receptor molecules. Polimerised actin is shown. The scheme does not account for morphological differences between ingestion undertaken by professionals or amateur phagocytes. We may however speculate that a situation type $\mathrm{C}$ or $\mathrm{A}$, respectively, occurs 
be necessary to reinforce tethering around the prey via the local recruitment of multiple low potency molecules (Figure 1b). In this modified version of the classical zipper mechanism $^{53}$ reinforcement does not come from the multiplication of the same receptor/ligand interaction but rather from the concerted action of several distinct receptor/ ligand pairs, all concomitantly activating a common signalling cascade. Finally, redundancy could barely reflect topological constraints (Figure 1c). Indeed preferential start sites for engulfment may exist on the cell surface as specialised membrane domains. It is here relevant to underline that most if not all the engulfment receptors are enriched in detergent insoluble membrane domains or rafts. ${ }^{54-57}$ Considering the recent developments indicating the existence of a multiplicity of rafts with diverse biochemical features, ${ }^{58-60}$ it would be of interest to establish whether the plethora of engulfment receptors is clustered in domains of the same size and floating characteristics on a macrophage which lacks canonical caveolae. This view brings us back to the fluidity of the membrane, or more generally, to its biophysical properties as determinants for the efficiency of engulfment. Local lipid homeostasis is the critical determinant of the biophysical characteristics of a membrane domain and, intriguingly, lipid metabolism or cellular cholesterol trafficking are key words frequently associated to engulfment. Class $A$ and $B$ scavenger receptor mediate cholesterol influx from high density lipoproteins, ${ }^{61-64}$ whereas $A B C 1$ function controls the Apolipoprotein $A-I$ mediated extraction from cell membranes of phospholipids and cholesterol. ${ }^{65}$ Similarly depletion/repletion of plasma membrane cholesterol is known to affect the lateral diffusion parameters of lipid species $^{66-69}$ and is thus likely to exert a dramatic impact on events requiring impressive membrane turnover and plasticity like engulfment. ${ }^{70,71}$ Disclosing the details of the relationship between lipid dynamics and the safe elimination of dying cells may well become the challenge of the new millennium.

\section{Acknowledgements}

The author wishes to thank all colleagues in the labs and in the engulfment field.

\section{References}

1. Wyllie AH, Kerr JFR and Currie AR (1980) Cell death: the significance of apoptosis. Int. Rev. Cytol. 68: 251-306

2. Kerr JFR, Wyllie AH and Currie AR (1972) Apoptosis: a basic biological phenomenon with wide-ranging implication in tissue kinetics. Br. J. Cancer 26 : $239-257$

3. Hopkinson-Woolley J, Hugues D, Gordon S and Martin P (1994) Macrophage recruitment during limb development and wound healing in the embryonic and foetal mouse. J. Cell Science 107: 1159-1167

4. Gumienny TL and Hengartner M (2001) How the worm removes corpses: the nematode C. elegans as a model system to study phagocytosis. Cell Death Differ., this issue

5. Hengartner MO and Horvitz HR (1994) Programmed cell death in Caernorhabditis elegans. Curr. Opin. Genet. Develop. 4, 581-586
6. Savill J and Fadok V (2000) Corpse clearance defines the meaning of cell death. Nature 407, 784-788

7. Savill J (1998) Phagocytic docking without shocking. Nature 392, 442-443

8. Ren Y and Savill J (1998) Apoptosis: the importance of being eaten. Cell Death Differ. 5, 563-568

9. DeKoter RP, Walsh JC and Singh H (1998) PU.1 regulates both cytokinedependent proliferation and differentiation of granulocyte/macrophage progenitors. EMBO J. 17: 4456-4468

10. DeKoter RP and Singh H (2000) Regulation of B lymphocyte and macrophage development by graded expression of PU.1. Science 288: 1439-1441

11. Wood W, Turmaine M, Weber R, Camp V, Maki RA, McKercher SR and Martin P (2000) Mesenchymal cells engulf and clear apoptotic footplate cells in macrophageless PU.1 null mouse embryos. Development 127: 5245-5252

12. McKercher SR, Torbett BE, Anderson KL, Henkel GW, Vestal DJ, Baribault $H$, Klemsz M, Feeney AJ, Wu GE, Paige CJ and Maki RA (1996) Targeted disruption of the PU.1 gene results in multiple hematopoietic abnormalities. EMBO J. 15: $5647-5658$

13. Hamon Y, Broccardo C, Chambenoit O, Luciani MF, Toti F, Chaslin S, Freyssinet JM, Devaux P, Neish J, Marguet D and Chimini G (2000) ABC1 promotes engulfment of apoptotic cells and transbilayer redistribution of phosphatidylserine. Nature Cell Biol. 2: 399-406

14. Taylor PR, Carugati A, Fadok VA, Cook HT, Andrews M, Carroll MC, Savill JS, Henson PM, Botto M and Walport MJ (2000) A hierarchical role for classical pathway complement proteins in the clearance of apoptotic cells in vivo. J. Exp.Med. 192: 359-366

15. Febbraio M, Podrez EA, Smith JD, Hajjar DP, Hazen SL, Hoff HF, Sharma K and Silverstein RL (2000) Targeted disruption of the class B scavenger receptor CD36 protects against atherosclerotic lesion development in mice. J. Clin. Invest. 105: 1049-1056

16. Platt N, Suzuki H, Kodama T and Gordon S (2000) Apoptotic thymocyte clearance in scavenger receptor class A-deficient mice is apparently normal. J. Immunol. 164: 4861-4867

17. Moore KJ, Andersson LP, Ingalls RR, Monks BG, Li R, Arnaout MA, Golenbock DT and Freeman MW (2000) Divergent response to LPS and bacteria in CD14deficient murine macrophages [In Process Citation]. J. Immunol. 165: 42724280

18. Haziot A et al. (1996) Resistance to endotoxin shock and reduced dissemination of gram-negative bacteria in CD14-deficient mice. Immunity 4: 407-414

19. Febbraio M, Abumrad NA, Hajjar DP, Sharma K, Cheng W, Pearce SF and Silverstein RL (1999) A null mutation in murine CD36 reveals an important role in fatty acid and lipoprotein metabolism. J. Biol. Chem. 274, 19055-19062

20. Gregory CD (2000) CD14-dependent clearance of apoptotic cells: relevance to the immune system. Curr. Opin. Immunol. 12: 27-34

21. Huh HY, Pearce SF, Yesner LM, Schindler JL and Silberstein RL (1996) Regulated expression of CD36 during monocyte-to-macrophage differentiation: potential role of CD36 in foam cell formation. Blood 87: 2020-2028

22. Wright SD, Ramos RA, Tobias PS, Ulevitch RJ and Mathison JC (1990) CD14, a receptor for complexes of lipopolysaccharide (LPS) and LPS binding protein. Science 249: 1431-1433

23. Haworth R, Platt N, Keshav S, Hughes D, Darley E, Suzuki H, Kurihara Y, Kodama T and Gordon S. (1997) The macrophage scavenger receptor type A is expressed by activated macrophages and protects the host against lethal endotoxic shock. J. Exp. Med. 186: 1431-1439

24. Fadok V, Bratton DL, Frasch SC, Warner M and Henson PM (1998) The role of Phosphatidylserine in recognition of apoptotic cells by phagocytes. Cell Death Differ. 5: 551-562

25. Marguet D, Luciani MF, Moynault A, Williamson P and Chimini G (1999) Engulfment of apoptotic cells involves the redistribution of membrane phosphatidylserine on both phagocyte and prey. Nature Cell Biol. 1: 454-456

26. Callahan MK, Williamson P and Schlegel RA (2000) Surface expression of phosphatidylserine on macrophages is required for phagocytosis of apoptotic thymocytes. Cell Death Differ. 7: 645-653

27. Schlegel RA and Williamson P (2001) Phosphatidylserine, a death knell. Cell Death Differ., this issue

28. Fadok VA, Xue D and Henson $P$ (2001) If phosphatidylserine is the death knell, a new phosphatidylserine specific receptor is the bell ringer. Cell Death Differ., this issue 
29. Fadok VA, Bratton DL, Rose DM, Pearson A, Ezekewitz RA and Henson PM (2000) A receptor for phosphatidylserine-specific clearance of apoptotic cells. Nature 405: 85-90

30. Tepper AD, Ruurs P, Widemer T, Sims PJ, Borst J and van Blitterswijk WJ (2000) Sphingomyelin hydrolysis to ceramide during the execution phase of apoptosis results from phospholipid scrambling and alters cell-surface morphology [see comments]. J. Cell. Biol. 150: 155-164

31. Luciani MF and Chimini G (1996) The ATP binding cassette transporter ABC1, is required for the engulfment of corpses generated by apoptotic cell death. EMBO J. $15: 226-235$

32. Wu Y and Horvitz RH (1998) The C. elegans cell corpse engulfment gene ced-7 encodes a protein similar to $A B C$ transporters. Cell 93: 951-960

33. Young SG and Fielding CJ (1999) The ABCs of cholesterol efflux. Nature Genet. 22: $316-318$

34. Rust S, Rosier M, Funke H, Real J, Amoura Z, Piette JC, Deleuze JF, Brewer HB Duverger N, Denefle P and Assmann G (1999) Tangier disease is caused by mutations in the gene encoding ATP-binding cassette transporter 1. Nature Genet. 22: 352-355

35. Lawn RM, Wade DP, Garvin MR, Wang X, Schwartz K, Porter JG, Seilhamer JJ, Vaughan AM and Oram JF (1999) The tangier disease gene product ABC1 controls the cellular apolipoprotein-mediated lipid removal pathway. J. Clin. Invest. 104: R25-R31

36. Orso E, Broccardo C, Böttcher A, Liebisch G, Drobnik W, Kaminski W Chambenoit O, Götz A, Diederich W, Spruss T, Luciani MF, Roth G, Lackner KJ Chimini G and Schmitz G (2000) ABC1 mediates the cellular export of cholesterol and phospholipids: defective golgi to plasma membrane lipid transport in $A B C 1$ null mice and Tangier Disease. Nature Genet. 24: 192-196

37. McNeish J, Aiello RJ, GuyotD, Turi T, Gabel C, Aldinger C, Hoppe KL, Roach ML, Royer LJ, de Wet J, Broccardo C, Chimini G and Francone OL (2000) High density lipoprotein deficiency and foam cell accumulation in mice with targeted disruption of ATP-binding cassette transporter-1. Proc. Natl. Acad. Sci. USA 97: $4245-4250$

38. Zhou Z, Hartwieg E and Horvitz RH (2001) CED-1 is a transmembrane receptor that mediates cell corpse engulfment in C. elegans. Cell 104: 43-56

39. Finnemann SC and Rodriguez-Boulan E (1999) Macrophage and retinal pigment epithelium phagocytosis: apoptotic cells and photoreceptors compete for alphavbeta3 and alphavbeta5 integrins, and protein kinase $C$ regulates alphavbeta5 binding and cytoskeletal linkage. J. Exp. Med. 190: 861-874

40. Albert M, Kim J and Birge RB (2000) $\alpha v \beta 5$ integrin recruits the Crkll-Dock180Rac1 complex for phagocytosis of apoptotic cells. Nature Cell. Biol. 2: 899-906

41. Stern M, Savill J and Haslett C (1996) Human monocyte-derived macrophage phagocytosis of senescent eosinophils undergoing apoptosis. Mediation by alpha $v$ beta $3 / \mathrm{CD} 36 /$ thrombospondin recognition mechanism and lack of phlogistic response. Am. J. Pathol. 149: 911-921

42. Finnemann SC, Bonilha VL, Marmorstein AD and Rodriguez-Boulan E (1997) Phagocytosis of rod outer segments by retinal pigment epithelial cells requires alphavbeta5 integrin for binding but not for internalization. Proc. Natl. Acad. Sci. USA 94: 12932-12937

43. Maegher LC, Savill J, Baker A, Fuller RW and Haslett C (1992) Phagocytosis of apoptotic neutrophils does not induce release of thromboxaneB2. J. Leukoc. Biol. 52, 269-273

44. Haslett C, Savill JS, Whyte KB, Stern M, Dransfield I and Meagher LC (1995) Granulocyte apoptosis and the control of inflammation. In The role of apoptosis in development, tissue homeostasis and malignancies, Dexter TM, Raff M, Wyllie A, eds (Chapman \& Hall, London) pp 91-99

45. Fadok V, Savill J, Haslett C, Bratton DL, Doherty DE, Campbell PA and Henson PM (1992) Different population of macrophages use either the vitronectin receptor or the phosphatidylserine receptor to recognize and remove apoptotic cells. J. Immunol. 149: 4029-4035

46. Rubartelli A, Poggi A and Zocchi MR (1997) The selective engulfment of apoptotic bodies by dendritic cells is mediated by the alpha(v)beta3 integrin and requires intracellular and extracellular calcium. Eur. J. Immunol. 27: 1893-1900

47. Albert ML, Pearce SF, Francisco LM, Sauter B, Roy P, Silverstein RL and Bhardwaj N (1998) Immature dendritic cells phagocytose apoptotic cells via alphavbeta5 and CD36, and cross-present antigens to cytotoxic T lymphocytes. J. Exp. Med. 188: $1359-1368$
48. Bellone M, lezzi G, Rovere P, Galati G, Ronchetti A, Protti MP, Davoust J, Rugarli $C$ and Manfredi AA (1997) Processing of engulfed apoptotic bodies yields T cell epitopes. J. Immunol. 159: 5391-5399

49. Reddien PW and Horvitz HR (2000) CED-2/Crkll and CED-10/Rac control phagocytosis and cell migration in caenorhabditis elegans. Nat. Cell. Biol. 2: $131-136$

50. Caron E and Hall A (1998) Identification of two distinct mechanisms of phagocytosis controlled by different Rho GTPases. Science 282: 1717-1721

51. Aderem A and Underhill DM (1999) Mechanisms of phagocytosis in macrophages. Annu. Rev. Immunol. 17: 593-623

52. Parnaik R, Raff MC and Scholes J (2000) Differences between the clearance of apoptotic cells by professional and non-professional phagocytes. Curr. Biol. 10: $857-860$

53. Chimini $G$ and Chavrier $P(2000)$ Function of Rho family proteins in actin dynamics during phagocytosis and engulfment. Nat. Cell. Biol. 2: E191-E196

54. Dorahy DJ, Lincz LF, Meldrum CJandBurns GF (1996)Biochemical isolation of a membrane microdomain from resting platelets highly enriched in the plasma membrane glycoprotein CD36. Biochem. J. 319: 67-72

55. Oliferenko S, Paiha K, Harder T, Gerke V, Schwarzler C, Schwarz H, Beug H, Gunthert U and Huber LA (1999) Analysis of CD44-containing lipid rafts: Recruitment of annexin Il and stabilization by the actin cytoskeleton. J. Cell. Biol. 146: $843-854$

56. Kellner-Weibel G, de La Llera-Moya M, Connelly MA, Stoudt G, Christian AE, Haynes MP, Williams DL and Rothblat GH (2000) Expression of scavenger receptor $\mathrm{BI}$ in COS-7 cells alters cholesterol content and distribution. Biochemistry 39: 221-229

57. Cebecauer M, Cerny J and Horejsi V (1998) Incorporation of leucocyte GPIanchored proteins and protein tyrosine kinases into lipid-rich membrane domains of COS-7 cells. Biochem. Biophys. Res. Commun. 243: 706-710

58. Simons K and Toomre D (2000) Lipid rafts and signal transduction. Nature Rev. 1: $31-39$

59. Roper K, Corbeil D and Huttner WB (2000) Retention of prominin in microvilli reveals distinct cholesterol-based lipid micro-domains in the apical plasma membrane. Nat. Cell. Biol. 2: 582-592

60. Brown DA and London E (1998) Functions of lipid rafts in biological membranes. Annu. Rev. Cell. Dev. Biol. 14: 111-136

61. Rigotti A, Acton SL and Krieger M (1995) The class B scavenger receptors SR-BI and CD36 are receptors for anionic phospholipids. J. Biol. Chem. 270: 16221 16224

62. Trigatti B, Rigotti A and Krieger M (2000) The role of the high-density lipoprotein receptor SR-BI in cholesterol metabolism. Curr. Opin. Lipidol. 11: 123-131

63. Rigotti A and Krieger M (1999) Getting a handle on 'good' cholesterol with the high-density lipoprotein receptor. N. Engl. J. Med. 341: 2011-2013

64. Rigotti A, Trigatti BL, Penman M, Rayburn H, Herz J and Krieger M (1997) A targeted mutation in the murine gene encoding the high density lipoprotein (HDL) receptor scavenger receptor class B type I reveals its key role in HDL metabolism. Proc. Natl. Acad. Sci. USA 94: 12610-12615

65. Fielding PE, Nagao K, Hakamata H, Chimini G and Fielding CJ (2000) A two-step mechanism for free cholesterol and phospholipid efflux from human vascular cells to apolipoprotein A-1. Biochemistry 39: 14113-14120

66. Rietveld A and Simons K (1998) The differential miscibility of lipids as the basis for the formation of functional membrane rafts. Biochim. Biophys. Acta 1376, 467-479

67. Boesze-Battaglia K and Schimmel R (1997) Cell membrane lipid composition and distribution: implications for cell function and lessons learned from photoreceptors and platelets. J. Exp. Biol. 200: 2927-2936

68. Raffy S and Teissie J (1999) Control of lipid membrane stability by cholesterol content. Biophys. J. 76: 2072-2080

69. Devaux PF (1991) Static and dynamic lipid asymmetry in cell membranes. Biochemistry 30: 1163-1170

70. Shin JS, Gao Z and Abraham SN (1999) Bacteria-host cell interaction mediated by cellular cholesterol/glycolipid-enriched microdomains. Biosci. Rep. 19:421 432

71. Gatfield $\mathrm{J}$ and Pieters $\mathrm{J}(2000)$ Essential role for cholesterol in entry of mycobacteria into macrophages. Science 288: 1647-1650 